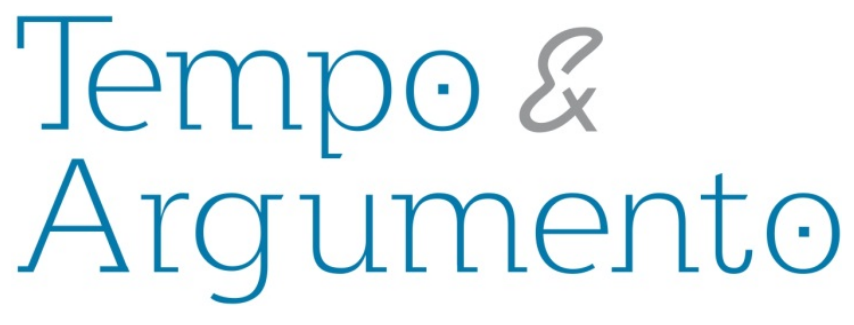

\title{
Plasmando a história: sofística, retórica do tempo e ficção
}

\begin{abstract}
Resumo
O artigo faz parte de uma investigação ${ }^{1}$ sobre o problema do falso e da ficção em história, tópico concernente aos estudos sobre a narrativa na historiografia. Partindo da controvérsia envolvendo a primeira sofística e a filosofia platônico-eleata acerca da referencialidade entre discurso e realidade, analisaremos possíveis analogias entre o logos sofístico e o narrativismo histórico enquanto valorizadores da multiplicidade de discursos. Em seguida, apresentaremos a crítica desferida pela retórica sofística (caracterizada como uma retórica inserida no tempo) ao historicismo. Por fim, avaliaremos a relação entre história e sofística enquanto atividades passíveis de serem plasmadas, i. é, moldadas, em uma operação que é ao mesmo tempo demiúrgica e ficcional.
\end{abstract}

Palavras-chave: História; Historiografia; Sofista; Retórica.

\author{
Veridiano Koeffender Moreira \\ Licenciado em História pela Universidade \\ Federal do Rio Grande do Sul. Mestrando \\ pelo Programa de Pós-Graduação em \\ História pela Universidade Federal do Rio \\ Grande do Sul \\ Brasil. \\ veridiano@ufrgs.br
}

\section{Para citar este artigo: \\ MOREIRA, Veridiano Koeffender. Plasmando a história: sofística, retórica do tempo e ficção. \\ Revista Tempo e Argumento, Florianópolis, v. 6, n. 12, p. 242 - 264, mai./ago. 2014.}

DOI: $\mathbf{1 0 . 5 9 6 5 / 2 1 7 5 1 8 0 3 0 6 1 2 2 0 1 4 2 4 2}$

http://dx.doi.org/10.5965/2175180306122014242

\footnotetext{
${ }^{1}$ Pesquisa conduzida em mestrado na linha da teoria da história e da historiografia.
} 


\title{
Shaping the story: sophistics, rhetoric of the time and fiction
}

\begin{abstract}
This article is part of an investigations concerning problem of fake and fiction in history, topic concerning in studies of the narrative in historiography. Starting from the controversy surrounding the first sophistic and Platonic-Eleatic philosophy about referentiality between discourse and reality, we analyze possible analogies between sophistical logos and historic narrativism as exploiters of the multiplicity of discourses. Next, we present the critical performed by sophistic rhetoric (characterized as a rhetorical inserted in time) to historicism. Finally, we evaluate the relationship between history and sophistics as activities that can be shaped, ie: molded, in an operation that is both demiurge and fictional.
\end{abstract}

Keywords: History. Historiography. Sophist. Rhetoric.

\section{Introdução}

O historiador norte-americano Hayden White (1995), em Meta-história: a imaginação histórica do século XIX (WHITE, 1995), percebeu que a narrativa histórica funcionava de modo arbitrário em relação ao acontecimento. Uma primeira consequência disso, constatou, é que existe algo definitivamente artificial no logos do historiador, de tal modo que não possa refletir a natureza das coisas em si mesmas. Apesar de relativamente recentes (iniciados por volta dos anos 1970) na história, muito dos essenciais problemas da linguagem já haviam sido reconhecidos no mundo antigo. 
Na Grécia clássica, a sofística serviu como ponto de partida para a constatação de que a palavra proferida, desvinculada do conteúdo real a que anteriormente se presumia dirigir, convertia-se em instrumento específico, polivalente e privilegiado das relações sociais. ${ }^{2}$ No mundo historiográfico, a partir do linguist turn, ocorreu o mesmo, embora essa afirmação, aplicada a eventos-limite, não pareça ter funcionado muito bem. Nossa hipótese sugere como possível resposta um mal-entendido do que é a sofística, um malentendido sustentado pela tradição platônica que tanto influenciou o pensamento ocidental que culminou numa espécie de "crise do logos".

Um dos pontos amplamente disputados entre a sofística e o platonismo diz respeito justamente à nossa primeira questão: o debate sobre a natureza da linguagem -

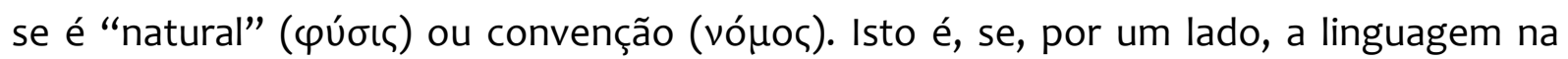
verdade representa o mundo externo, e se os nomes, inerentes aos objetos, estão disponíveis para a correta designação das coisas; ou se, por outro lado, as palavras são meramente convencionais e arbitrariamente impostas por nós aos objetos, utilizadas numa linguagem sem nenhuma conexão com qualquer mundo externo. Assim, Crátilo, segundo Platão, é alguém que acredita que um "poder mais que humano deu às coisas seus primeiros nomes, e estes nomes que lhes foram dados são seus verdadeiros nomes". (PLATÃO, Crátilo, 438c.) Desse modo, na teoria referencial de Crátilo, "aquele que descobre o nome, descobre também a coisa" (PLATÃO, Crátilo, 435e) e, pela aplicação adequada da linguagem, o mesmo indivíduo pode penetrar na verdade das coisas mesmas, pois conhece sua natureza reveladora.

Esta tese filosófica encontra fácil paralelo na história. É apenas preciso que lembremos as infindáveis discussões em história: 1964, no Brasil, foi golpe ou revolução? O Estado moderno foi burguês ou aristocrata? Por trás dessas conceituações existe, evidentemente, a crença de que o nome ou conceito adequado poderá revelar a real natureza do evento. Mas estaria alguém, com efeito, em posição privilegiada da qual

\footnotetext{
${ }^{2}$ Uma reflexão sobre a linguagem é elaborada em duas grandes direções: por uma parte, sobre o logos como instrumento das relações sociais; por outra, sobre o logos como meio de conhecimento da realidade. A retórica e a sofística seguem a primeira via, forjando técnicas de exploração, desenvolvendo a análise gramatical e estilística do novo instrumento, enquanto a segunda via se converte em objeto da reflexão filosófica. Ver DETIENNE, Marcel. Les Maîtres de Verité dans la Grèce archaïque. Paris: Maspéro, 1981. p. 103.
} 
poderia ter um conhecimento real sobre o mundo externo, que serviria então como critério através do qual poderia avaliar a confiabilidade da crença ou a verdade das várias descrições enunciadas? (SOUTHGATE, 1996, p. 71) Este é um dos principais problemas, explorado no Crátilo, acerca da dificuldade de alguém poder avaliar os dados externos sem recorrer a uma descrição, expressa também em termos linguísticos. Diga-se de passagem, este é precisamente um dos problemas enfrentados pela história, como observou Ankersmit (1999):

If language is an object in the world like the objects language is about, the category of objects in the world can no longer, as is traditionally argued, distinguish between fact and fiction - or between historical writing and the novel. The gap between language and reality can no longer function as the reliable criterion for distinguishing between the two. What is, or has been written is as much a source of truth as the other objects of the world and the investigation of texts can generate new and unxepected truth. ${ }^{3}$

Mas, contra a perspectiva de Ankersmit, a sabedoria aspirada pelo Crátilo platônico poderia reivindicar a condição divina. Não por acaso, na concepção eleata, é a deusa que afavelmente acolhe o filósofo, para então tomar-lhe a mão direita entre as suas e instruí-lo no intrépido coração da verdade persuasiva (PARMÊNIDES. DK 28B 1.2130):

Para descobrir o que realmente é, o filósofo deve deixar o mundo das aparências entre as quais ele naturalmente e originalmente se encontra em casa - como fez Parmênides quando foi transportado, além dos umbrais da noite e do dia, para a estrada divina, "muito distante dos usuais caminhos humanos", e como também fez Platão na alegoria da Caverna. O mundo das aparências é anterior a qualquer região que o filósofo possa escolher como sua "verdadeira" morada, mas que, no entanto, não é o local em que ele nasceu. O que sugeriu ao filósofo, ou seja, ao espírito humano, a noção de que deve haver algo que seja mera aparência sempre foi a qualidade que o mundo tem de aparecer. (ARENDT, 2010, p. 39-40)

\footnotetext{
${ }^{3}$ Se a linguagem é um objeto no mundo assim como os objetos da linguagem também o são, a categoria de objetos do mundo não pode mais, como é tradicionalmente arguído, distinguir entre fato e ficção - ou entre a escrita histórica e romance. A diferença entre a linguagem e realidade já não pode funcionar como critério confiável para distinguir entre os dois. O que é, ou tem sido escrito, é tanto uma fonte de verdade como os outros objetos do mundo e a investigação de textos pode gerar novas e surpreendentes verdades. (tradução nossa). ANKERSMIT, Frank. Truth in literature and history. In: Geschichstdiskurs. Band 5: Globale Konflikte, Erinnerungsarbeit und Neuorientierungenseit 1945 , Wolfgang Küttler, Jörn Rüsen, Ernst Schulin Hrsgb. Frankfurt am Main: Fischer Taschenbuch Verlag, 1999 : 337 - 360.
} 


\section{Do logos sofístico ao narrativismo histórico: a valorização dos múltiplos} discursos

A sabedoria sofística, por sua vez, situa-se em outro plano. Na concepção sofística, o ser humano, irremediavelmente marcado por suas limitações e consciente delas, não pode conhecer a realidade das coisas em si mesmas, nem formular a verdade absoluta e eterna. O homem, confinado no universo das sensações (e sem acesso às formas platônicas), enuncia por meio do logos as opiniões contrárias e múltiplas sobre as coisas. Desse modo, a verdade produzida pelo homem, e por ele colocada na história, se torna perfectível, mas jamais revelada. Instituída como verdade laica e desconectada das anteriores credenciais divinas, seu valor agora reside na força persuasiva de seu discurso e na eficácia da argumentação do orador perante o auditório que pretende convencer. (PINTO, 2000, p. 76)

Segundo Marcel Detienne (1981), no mundo grego, a palavra mágico-religiosa primeiramente enunciada pelos poetas (mas depois reivindicada pelos filósofos, como vimos) opôs-se à palavra laicizada, proferida num âmbito mundano, no qual assumiu a forma de palavra-diálogo:

Estes dois tipos de palavras opõem-se numa série de pontos: a primeira é eficaz, intemporal; é inseparável de condutas e de valores simbólicos; constitui o privilégio de um ser excepcional. Pelo contrário, a palavradiálogo é laicizada, complementar da ação, inscrita no tempo, provida de uma autonomia própria e alargada às dimensões de um grupo social. (DETIENNE, 1981, p. 103)

Como destacou Maria Vaz Pinto, existe um aspecto fundamental que diferencia uma da outra: enquanto a primeira é assertórica, indiferente à aprovação do auditório, a segunda buscará sempre convencer, e, por isso, apresentará suas razões. A partir de certo momento, a palavra, como instrumento de poder na pólis, já não conta mais com suas prerrogativas religiosas. O confronto de discursos opostos, que supõe um auditório ao qual se dirija, passa a contar cada vez mais com os expedientes retóricos e sofísticos para determinar o logos vencedor. (PINTO, 2000, p. 76) Este é um processo no qual o logos humano se autonomiza progressivamente em relação ao logos mítico-religioso, um processo no qual a verdade deixa de se apoiar na ordem transcendente das coisas, seja 
ela entendida como meio de inspiração ou revelação, seja como forma de descoberta e/ou desocultação da lei divina, inerente ao cosmos.

A própria noção de tempo histórico é diferente numa e noutra concepção: enquanto a palavra revelada, seja ela poética ou filosófica, se inscrevia num pano de fundo religioso, dominado pela perenidade e repetição do tempo cíclico, no qual a visão dos deuses ou das formas captava a completude estável do universo em que nada havia de verdadeiramente novo, a palavra dialogada se inscreve no plano laico - onde se situa a ação dos novos educadores e oradores - os sofistas - e corre num tempo linear, construído pelo trabalho e pelos esforços dos homens. (PINTO, 2000, p. 77)

Essa mudança de atitude em relação à natureza do logos não passou incólume no mundo grego. A principal consequência foi em relação às leis, pois se tornava manifesto que, sendo elas criações humanas, já não cobravam a sua legitimidade divina. (PINTO, 2000, p. 78) Não aprofundaremos esta questão, pois ela diz respeito mais à consequência que a sofística originou no debate sobre o "verdadeiro justo", tópico polêmico da reflexão ética e política. Importa, por ora, retomarmos o ponto no qual a reflexão sofística pensou o logos como instrumento que poderia dar conta de uma natureza que apresenta aspectos contrários.

A natureza tem aspectos múltiplos; por isso, ela se presta para que sobre ela se façam duplos discursos. Da mesma forma, o fato de a realidade humana ser determinada por condicionamentos díspares demanda também que a palavra, dirigida a cada um, tenha múltiplas vertentes, ajustando-se aos casos particulares. (PINTO, 2000, p. 88) Na história, Paul Veyne (1987) alude a tal situação através de um exemplo por meio do qual expressa a impossibilidade de se fazer um discurso unificado acerca do acontecimento de Waterloo:

Waterloo não foi a mesma coisa para um veterano e para um marechal, quer se possa contar esta batalha na primeira ou na terceira pessoa, falar dela como de uma batalha, de uma vitória inglesa ou de uma derrota francesa, quer se possa deixar antever desde o princípio qual foi o epílogo ou fingir descobri-lo; estas especulações podem dar lugar a divertidas experiências de estética para o historiador; são a descoberta de um limite. [...] Mesmo que eu fosse contemporâneo e testemunha de Waterloo, mesmo que eu fosse o principal ator e Napoleão em pessoa, teria somente uma perspectiva sobre o que os historiadores chamarão de o acontecimento de Waterloo; não poderei jamais deixar à 
posteridade mais do que o meu testemunho, a que ela chamará vestígio se chegar até ela. Mesmo se eu fosse Bismarck que toma a decisão de expedir o despacho de Ems, a minha própria interpretação do acontecimento não seria talvez a mesma dos meus amigos, do meu confessor, do meu historiador oficial e do meu psicanalista, que poderão ter a sua própria versão da minha decisão e pretender saber melhor que eu o que eu queria. (VEYNE, 1987, p. 14-15)

O logos, na sofística, pretendeu ser o meio por excelência através do qual se expressava e se formulava a verdade das coisas cambiantes. Por isso, o fundamento da sua veracidade radicava na própria realidade, que era mutável. ${ }^{4}$ Mas essa alternativa de razão sofística sustentou que poderia não haver sentido em se pretender proferir sobre a realidade um discurso único, verdadeiro em termos absolutos e universais. Diante do espetáculo dos fenômenos e da experiência, a sofística valorizou os antagonismos expressos, admitindo, desse modo, a multiplicidade de discursos que poderiam ser enunciados acerca da natureza, mas, sobretudo, do mundo humano. (PINTO, 2000, p. 111)

Por outro lado, tal tese também enfrentou desafios. O principal deles, enunciado em Platão e Aristóteles, foi também recuperado por Carlo Ginzburg em sua defesa do realismo histórico. Este desafio diz respeito à salvaguarda de um critério fidedigno de verdade, uma vez que o fundamento ontológico da verdade clássica havia sido rejeitado. Em todo caso, a chamada crise do logos científico conduz invariavelmente a uma

\footnotetext{
${ }^{4}$ Esse ponto de vista foi expresso em um texto intitulado Duplos Discursos (Dissoi Logoi), encontrado entre os manuscritos de Sexto Empírico, mas escrito por volta de 400 a.C., em dialeto dórico com elementos jônicos, com conteúdo sobre assuntos diversos, mas expressando pontos de vista amplamente sofísticos: "Duplos discursos sobre o bem e o mal são proferidos na Grécia por aqueles que se dedicam à filosofia. Uns dizem que uma coisa é o bem e outra coisa é o mal; mas outros dizem que são o mesmo, e que uma coisa é um bem para uns, enquanto para outros é um mal ou que, para a mesma pessoa, uma coisa é um bem numa certa ocasião e um mal noutra ocasião. (2) Eu próprio partilho da perspectiva destes últimos e analisarei o argumento a partir da vida humana, cujos cuidados são a comida, a bebida e os prazeres sexuais; tudo isto é um mal para o que está doente, mas é um bem para o que está de saúde e deles sente necessidade. (3) E o desregramento nestas coisas é um mal para os desregrados, mas é um bem para quem negocia e os vende. $E$ a doença é um mal para os que estão doentes, mas é um bem para os médicos. E a morte é um mal para os que morrem, mas é um bem para os comerciantes de serviços funerários e para os fornecedores de túmulos. [...] (8) E na guerra (falarei primeiro dos acontecimentos mais recentes), a vitória dos Espartanos, que derrotaram os Atenienses e os aliados, foi um bem para os Espartanos, mas um mal para os Atenienses e Aliados. E a vitória que os Gregos obtiveram sobre os Persas foi um bem para os Gregos, mas um mal para os bárbaros. (9) Também a derrota de Tróia foi um bem para os Aqueus, mas um mal para os Troianos. E o mesmo em relação ao que passaram Tebanos e Argivos. (10) E o combate entre Centauros e os Lápitas foi um bem para os Lápitas, mas um mal para os Centauros. E também no famoso combate entre os Deuses e os Gigantes, a vitória foi um bem para os Deuses, mas um mal para os Gigantes."
} 
relativização da verdade, ao mesmo tempo em que passa a erigir a edificação do logos retórico. Essa mudança de atitude, que prevê o poder do discurso de construir diferentes leituras "verdadeiras" do real, ou ainda, pela via de Górgias, tornar-se independente de qualquer correlato, resulta em novo e singular impacto do logos sobre o auditório, razão pela qual Barbara Cassin (2005) evocou o conceito de efeito-mundo que a palavra produz:

O efeito-mundo se produz em dois níveis: o da fabricação do mundo humano do consenso que constitui a cidade, cultura por oposição à natureza; o da ficção literária, do patrimônio que constitui a identidade de um povo, cultura por oposição à incultura; com, certamente, para servir de ponte entre os dois, a paideia, instrução do filho do homem e educação do pequeno grego. (CASSIN, 2005, p. 219)

Esse efeito-mundo não estava destinado a revelar a razão de ser constitutiva do discurso numa perspectiva transcendental, muito menos como meio de conhecimento definitivo das coisas. Tal situação é comparável ao momento em que a história é confrontada com os acontecimentos. Todavia, se Waterloo, por um lado, pôde passar mais ou menos tranquila pelas águas da história, sem grande agitação, o mesmo não ocorreu com eventos mais recentes, sobretudo de caráter traumático, como o Holocausto. Mesmo assim, o ponto de partida proposto pela antiga sofística não parece ter sido descartado, ou pelo menos não por Dominick La Capra:

The Holocaust presents the historian with transference in the most traumatic form conceivable - but in a form that will vary with the difference in subject position of the analyst. Whether the historian or analyst is a survivor, a relative of survivors, a former Nazi, a former collaborator, a relative of former Nazis or collaborators, a younger Jew or German distanced from more immediate contact with survival, participation, or collaboration, or a relative "outsider" to these problems will make a difference even in meaning of statements that may be formally identical. Certain statements or even entire orientations may seem appropriate for someone in a given subject position but no in others. $^{5}$

\footnotetext{
${ }^{5} \mathrm{O}$ Holocausto apresenta ao historiador a noção de transferência na sua forma mais traumática concebível mas em uma forma que irá variar conforme a diferença de posição do sujeito analista. Se o historiador ou analista é um sobrevivente, um parente de sobreviventes, um ex-nazista, um ex-colaborador, um parente de ex-nazistas ou colaboradores, um jovem judeu ou alemão distanciado do contato mais imediato com a sobrevivência, a participação ou colaboração, ou um "outsider" em relação a estes problemas irá fazer uma diferença, mesmo no sentido de afirmações que podem ser formalmente idênticas. Certas declarações ou mesmo completas orientações podem parecer apropriadas para alguém em uma determinada posição de sujeito, mas não em outras. (tradução nossa) LA CAPRA, Dominik. Representing
} 
Como aponta La Capra, trata-se de retomar como ponto de partida a diversidade de situações nas quais as testemunhas são convocadas. Por isso La Capra utiliza o conceito de relação de transferência (transferential relation). Como Ricoeur oportunamente salienta, não se trata apenas de pontos de vista diferentes, mas de investimentos heterogêneos. La Capra está ciente disso, bem como do papel fundamental que a linguagem ocupa nesse processo: "how language is used is thus critical for the way in which a transferential relation is negotiated". ${ }^{6}$

Por ora, o que podemos dizer é que a sofística colocou a claro as dificuldades do

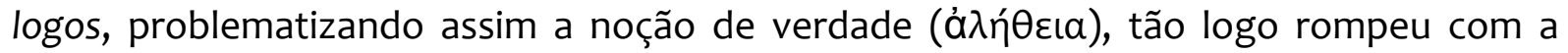
concepção platônica segundo a qual o discurso radicava na correspondência direta e unívoca das palavras com seus correlatos reais. A tese de que vários discursos poderiam se referir ao mesmo objeto - como sustentou a tropologia de White, ou, ainda, a arbitrariedade existente entre significante e significado, para usarmos expressões modernas da linguística, e que a relação existente é dada por convenção e não por natureza - libertou "o pensamento dos grilhões de uma verdade e de uma realidade originalmente dadas e possuídas, de uma verdade que é eterna", para abrir caminho a uma noção de verdade e critério como "resultado", como investigação e escolha. (PINTO, 2000, p. 121) Nessa troca, o sujeito falante, o autor - o sofista - é o demiurgo de um mundo que requer interpretação. A filósofa Barbara Cassin assinala aí uma espécie de visão perspectiva da segunda sofística sobre a sofística de um modo geral: "Entramos, com a ficção, o estilo, a exegese e a crítica literária, na era da hermenêutica". (CASSIN, 2005, p. 194) Se White, em seu Meta-história, falou em “imaginação histórica”, o termo nunca antes nos pareceu tão apropriado.

Cassin insistirá, como veremos, que a amplitude do termo história - históriainvestigação (nossa ciência histórica) e história-narrativa - faz com que se misture aquilo que nós, os modernos, não cessamos de querer manter separado: as ciências humanas e a ficção. O que pretendemos, a partir deste ponto, é demonstrar como a sofística poderia

the Holocaust: Reflections on the Historians' Debate. In: FRIEDLAND, Saul (Org.). Probing the limits of representation. Cambridge, London: Harvard University, 1992, p. 110.

6 “como a linguagem é usada é, portanto, essencial para o modo no qual uma relação transferencial é negociada” (tradução nossa).ld. Ibid. 
completar a história, na medida em que uma compreensão adequada de sua visão poderia inocentar a narrativa da acusação de perverter a história. ${ }^{7}$

\section{Retórica do tempo e ficção}

A primeira consideração relativa à retórica sofística diz respeito a uma velha conhecida de Clio: o tempo. O tempo, tão caro aos historiadores, foi central na concepção do logos sofístico, como veremos. Na perspectiva de Cassin, o fato de que Élio Aristides seja, como Górgias, um dos que teorizaram sobre a relação tempo e discurso, faz dele um “sofista”. Cassin sublinha que essa relação produziu duas concepções de logos: uma, ontológica, cuja matriz metafórica é o espaço; matriz metafórica, expressão do essencial, que funciona como paradigma, a interpretação heideggeriana do logos heraclitiano, concepção na qual os "fenômenos" são onta e o tempo, especializado em presença. (CASSIN, 2005, p. 200)

A outra, de caráter sofístico, é a logológica, que tem como matriz metafórica o tempo. Seu paradigma, ou tematização, reside no Tratado do não-ser e no Elogio de Helena. Sua divisa encontra fundamento na frase de Élio Aristides: "Os discursos caminham com o mesmo andamento do tempo", concepção na qual os "fenômenos" são

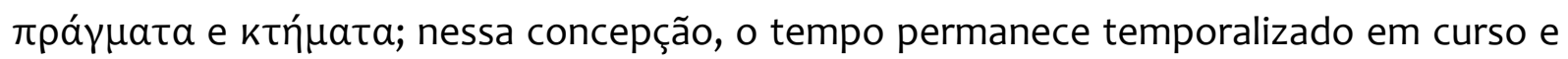
discurso e a potência do discurso se confunde com o tempo. Como resume a própria Cassin, o traço genérico das retóricas do tempo reside no fato de que o discurso, em sua sequência, não é projetado como uma totalidade fechada, "um öגov orgânico a ser recortado segundo um 'plano' e 'articulações”'; nem um $\pi \tilde{a} \nu$, mas, antes, um $\pi a ́ v \tau \alpha$ :

Uma pluralidade de emissões singulares necessariamente sucessivas: em que é evidente a relação, estigmatizada no Teeteto de Platão bem como

\footnotetext{
7 Barbara H. Smith, em nota, exemplifica as acusações recorrentes no pós-modernismo. Ela cita Gertrude Himmelfarb que, em um ponto alto de seu livro, escreve:

"A história pós-modernista, como a teoria literária pós-modernista, celebra a "aporia" - diferença, descontinuidade, disparidade, contradição, discórdia, ambigüidade, ironia, paradoxo, perversidade, opacidade, obscuridade, anarquia, caos [...] O modernista acusa o pós-modernista de conduzir a humanidade ao abismo do niilismo. O pós-modernista orgulhosa e alegremente aceita a acusação."

Em apoio a essa caracterização, ela cita uma passagem de Hayden White: "Necessitamos de uma história que nos eduque para a descontinuidade mais do que nunca; pois a descontinuidade, a ruptura e o caos é nosso legado". SMITH, Bárbara Herrnstein. Crença e resistência: A dinâmica da controvérsia intelectual contemporânea. São Paulo: Editora UNESP, 2002. p. 81.
} 
no livro Gama da Metafísica de Aristóteles, com o heraclitismo, senão com

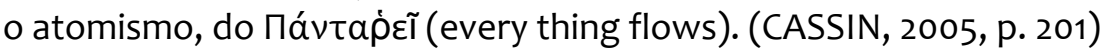

Desse modo, a logologia (o ser é um efeito do dizer) é uma cronologia, pois o tempo é o princípio realizador ou eficaz do discurso. Desse modo, o presente, e em especial o presente da enunciação, está incluído na cadeia, no fluxo do tempo, e dela não poderia ser retirado: a metalinguagem falha aqui. Surgem, no lugar, as contradições, as inversões - o império da paradoxologia. (CASSIN, 2005, p. 201) O paradigma desse estatuto sofístico, bem cedo ridicularizado e convertido em anedota, ajuda a entender: conta-se que, uma vez, o sofista Protágoras, depois de ter reclamado o pagamento a seu discípulo Evatlo que Ihe teria respondido "mas eu ainda não alcancei uma vitória", retrucara: "mas se eu vencer [esta disputa] devo receber pagamento, porque a venci; se a venceres tu, devo receber pagamento, porque tu a venceste". ${ }^{8}$ Eis o modelo de eloquência sofística, indissociável de tempo e razão, motivo pelo qual Cassin sustenta, apoiada nesse exemplo, que na logologia "o que produz o fato ou a causa como ficção é a imersão do logos no tempo".

A sofística, por isso, jamais pretenderia deslocar o sujeito histórico para uma posição metafísica e “des-historicizada". Uma tal retórica do tempo, oportuna e apropriada, uma "retórica do kaĩpoৎ", percebe o fluxo do tempo e age sobre ele, mas não pretende descolar-se dele, pois este movimento lhe é impossível. O fluxo - o rio do tempo - Ihe é index sui. Esta é ao mesmo tempo uma confissão de limitação e um gesto de honestidade da sofística. O historicismo (modernista), por sua vez, também reconhece o fluxo do tempo, mas do ponto de vista do historicista, as diferentes águas são percebidas somente como distintos pontos dessa torrente. Em outras palavras, o próprio historiador se encontra em uma elevação segura além do rio do tempo que corre abaixo dele, num lugar cuidadosamente apartado. (ANKERSMITH, 2006, p. 97-98)

\footnotetext{
${ }^{8}$ Diógenes Laércio, 9, 50 e segs. Como expõe Cassin, a eloquência sofística buscará não a revelação do ser, mas a produção de sentido, que por sua vez é criado ao longo da enunciação, não apenas no nível da argumentação, como acabamos de ver, mas no nível da sintaxe, da disposição das palavras. Foi a isso que Górgias recorreu no Tratado do não-ser, na medida em que explorou o caráter escorregadio de qualquer proposição de positividade: “o não-ente é [...]” [ele existe, portanto] “[...] enquanto não-ente”, diz ele. CASSIN, Barbara. O efeito sofístico: sofística, filosofia, retórica, literatura. São Paulo : Ed. 34, 2005. p. 202.
} 
As sofistiquices cheias de contradição e paradoxologia se mostraram honestas, pois admitem estar irremediavelmente inseridas no fluxo do tempo. O historicismo, por sua vez, não, razão pela qual foi acusado de contraditório por Gadamer e, nas palavras de Ankersmit, se quisermos tornar mais preciso o diagnóstico, de falta de sinceridade.

A questão fundamental, segundo Gadamer, é saber com que argumento ou em que condições se poderia deslocar o sujeito histórico para uma posição transcendental ou des-hisotiricizada.

A resposta de Ankersmit é que não temos razão alguma para duvidar de que o sujeito histórico esteja menos submetido ao domínio da história que os fenômenos históricos por ele estudados. (ANKERSMITH, 2006, p. 97-98)

O próprio Gadamer procurou superar a aporia do relativismo: o problema do discurso histórico no fluxo do tempo. Para isso, ele recorreu ao conceito de "história efeitual”, numa tentativa de mover-se em direção a uma hermenêutica histórica que pudesse superar os desafios do fluxo:

Um pensamento verdadeiramente histórico tem de refletir continuamente sobre sua própria historicidade. Só então ele deixará de perseguir o fantasma de um objeto histórico que é tema de investigação progressiva e aprenderá a reconhecer, no objeto, o distinto do próprio e, assim, tanto o próprio quanto o distinto. O verdadeiro objeto histórico não é objeto algum, mas a unidade desse próprio e desse distinto, uma relação na qual coexiste tanto a realidade da história quanto a realidade da compreensão histórica. Uma hermenêutica apropriada às coisas deveria mostrar na própria compreensão a realidade da história. Eu chamo de "história efeitual" o que é requerido com isso. Compreender é, essencialmente, um processo histórico-efeitual. (GADAMER, 1997, p. 448)

Novo platonismo aqui, pois a ideia de uma história efeitual, como destaca Ankersmit, permanece estranhamente coroada por uma pretensão de saber universal. Para retomar a discussão nos termos em que iniciamos este trabalho, ela dá margem à suposição de que "existe uma entidade nomeável à qual nos podemos remeter com o conceito de "história efeitual”". Prossegue o autor: "Toda tentativa de identificar essa entidade significa apenas que a afastamos ainda mais de nós". Por fim, a metáfora não poderia ser mais adequada: 
O esforço de dotar de substância o conceito de "história efeitual" causa tanta impressão quanto o esforço de se tentar pular sobre a própria sombra. Por que razão, afinal, nos detemos sobre a "história efeitual", por que razão não deveríamos historicizar a própria "história efeitual" (e assim por diante)? (ANKERSMITH, 2006, p. 99)

A hermenêutica da história efeitual, que se pretendeu resposta ao historicismo, caiu no mesmo redemoinho platônico - a eterna tentação do "fundamento" do ser histórico. O problema, no entanto, é que a história efeitual sobrepõe pontos de vista a outros pontos de vista, e como esse movimento não tem fim, não se chega nunca a um ponto de vista maior e absolutamente válido a partir do qual poderíamos deduzir e reconstruir os pontos de vista iniciais e fundamentais. Nas palavras de Ankersmit:

A historicização dos pontos de vista (históricos) dificulta não apenas a sua identificação" (eis o velho problema do relativismo, desde Platão), mas nos coloca também na estranha e improvável situação de assumirmos o ponto de vista que nós não temos ponto de vista algum. (ANKERSMITH, 2006, p. 100)

E isso é justamente o oposto que a posição sofística, de uma retórica do tempo, poderia assumir.

Do ponto de vista da perspectiva sofística, a história penetra num outro mundo, no qual uma filosofia do fundamento, convertida em historicismo moderno, não é mais ou não ocupa mais a única posição - provedora de referencialidade, de nome, método, sentido e temporalidade. Se a história deve ser sofística, entramos, de fato, também em ficção. No entanto, a pergunta a que deveríamos responder agora é: "O que significa dizer que se entra em ficção?" Significa considerar em que medida a história é uma atividade plástica, que persuade plasmando, modelando os eventos em narrativas verossímeis. Mas antes de tratar disso propriamente devemos apontar, com Cassin, um dado não menos relevante, que é o fato de que entrar em ficção/literatura na história é sinal também de que a filosofia platônico-aristotélica ganhou. Como diz a autora: “Mesmo se a retórica e a sofística triunfam na cena do mundo, senhoras do ouvido dos jovens, dos príncipes e das multidões", ou seja, mesmo que a sofística se mostre pertinente à história, ou a história desponte sofística, “é a filosofia que terá determinado 
a escolha do terreno - de seu terreno como literatura, não como filosofia, e mais precisamente como não-filosofia". (CASSIN, 2005, p. 214)

A filosofia pode tratar da literatura/ficção como um objeto e ditar regras estéticas, da mesma forma que o historicismo pode tentar dar conta do jogo estético dos conceitos; mas ela própria, e seu correlato na história, são obrigados a também se lembrar de que eles próprios são um discurso, um logos produzido com os estilos que lhes convêm. Ainda assim, um "escritor", prossegue Cassin, não tem - com tal e filosoficamente - o direito de se crer filósofo, e isso até os dias de hoje (evidentemente não sem contestações: Nietzsche é a lembrança imediata). O que se sugere aqui é um dos motivos - senão o motivo principal - da instituição desse distanciamento filosofiapoética, ou seu análogo história-ficção, que é o de acabar de vez com a sofística. (CASSIN, 2005, p. 215) Movidos por essa preocupação, retomaremos a argumentação da autora para evidenciar a intrínseca relação entre poética, literatura, ficção e história naquilo que ela chamou de "descompartimentar os gêneros".

Como sabemos, a primeira sofística perdeu a guerra filosófica. Desde o início da atuação dos sofistas profissionais, foi em nome da verdade que ela foi condenada. A acusação, elaborada por Platão e Aristóteles, pode ser sumariamente inscrita em torno do termo pseudos. Seja ele um pseudos objetivo - o "falso" -, pois "o sofista diz o que não é, o não-ser, e o que não é verdadeiramente ente, os fenômenos, as aparências"; seja um pseudos subjetivo - a "mentira" -, porque o sofista diz o falso com o intento de enganar, valendo-se de todos os recursos do logos, ao mesmo tempo linguísticos (homonímia dos termos), lógicos (raciocínios enganosos, sofismas), raciocínios propriamente ditos (inaptidão para o cálculo, tolices do outro) (CASSIN, 2005, p. 216) e, acrescentamos, psicológicos (deleita o auditório, move os espíritos por meio do pathos ( $\pi$ átoৎ) e manipula as paixões).

No jogo verdade-falsidade, a poesia se impõe como o primeiro ponto de contato entre pseudos e plasma, instituída pela tensão entre a filosofia e a sofística. A poética/ficção é filosófica por sua ligação com a verdade (não a verdade científica, mas aquela inspirada pelas musas). O poeta no mundo antigo representa as ações que dão a essência ou o universal das coisas de que fala, para fazê-las passar à memória. (CASSIN, 

aconteceu"), enquanto a poesia diz respeito ao universal, narrando o que poderia ter acontecido. (ARISTÓTELES, Poética, 1451b)

Por outro lado, a poética/ficção também é sofística. É o que indicam as palavras das musas durante o prólogo da Teogonia: "Sabemos muitas mentiras dizer símeis aos

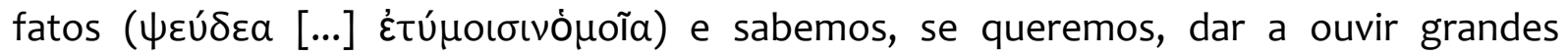

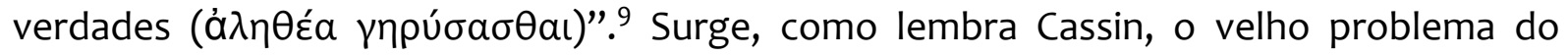
“verossímil” aristotélico. Assim, Aristóteles pode dizer que Homero, acima de tudo,

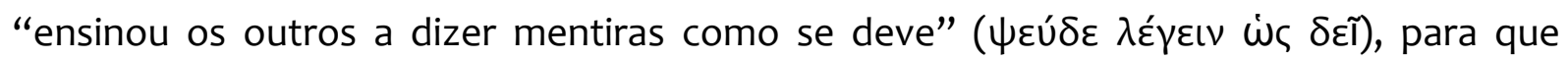
aqueles que as ouvem acreditem nelas. É a essa atividade demiúrgica que Cassin aplica o termo plasma, como expressão logológica (ser efeito de dizer) do pseudos. (CASSIN, 2005, p. 216-218)

O plasma, no sentido até agora retomado, tem uma de suas primeiras aparições no Elogio de Helena, de Górgias. Pouco antes do excerto no qual fala sobre a memória e o passado, Górgias faz referencia às artes gêmeas da feitiçaria e da magia (goeteia kai mageia), de modo que uma é "erros da alma” (psykhes hamartemata) e a outra, "enganos da opinião" (doxes apatemata), tendo sido identificadas, uma, como poesia, e outra, como retórica:

Os encantamentos inspirados pelas palavras levam ao prazer e libertam da dor. Na verdade, a força do encantamento, misturando-se com a opinião da alma, sedu-la, persuade-a e transforma-a por feitiçaria. Descobriram-se duas artes de feitiçaria e magia que são, uma os erros da alma e a outra os enganos da opinião. (GÓRGIAS, Helogio de helena, 10)

Em seguida, Górgias evoca todos os que até então persuadiram e persuadem

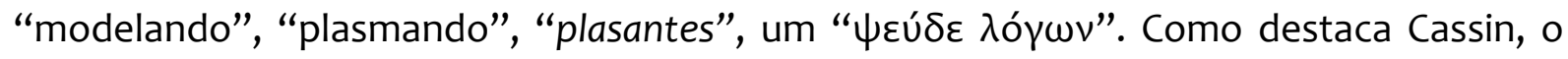
verbo utilizado - plasso -, formado a partir de uma raiz que denota justamente "estender uma camada fina, revestir" (por isso "gesso" [do francês: plâtre], “emplastro”), "fornece

\footnotetext{
${ }^{9}$ HESíODO. Teogonia. Tradução de José Antônio Alves Torrano. São Paulo: Massao Ohno e Roswitha Kempf Editores, 1981.
} 
o vocabulário específico do trabalho de argila e da modelagem, donde os empregos relativos à imaginação" (White escreveu seu meta-história para demonstrar como foi elaborada a imaginação histórica do século XIX). Imaginação que traz consigo todas as suas nuances: "Criação literária [aqui, novamente White], criação do homem por Deus, a mentira, etc.”. O verbo serve também, Cassin prossegue, para descrever a atividade de Prometeu, que, segundo se diz, nos modelou, bem como aos outros seres vivos:

Houve, na verdade, um tempo em que existiam deuses, mas não existia uma espécie de seres mortais. Quando chegou também para estes a ocasião do nascimento, fixada pelo destino, os deuses modelaram-nos no interior da terra, misturando terra e fogo e tudo o que se combina com fogo e terra. Quando estavam prestes a trazê-los para a luz, ordenaram a Prometeu e a Epimeteu que os dotassem de capacidades e as distribuíssem convenientemente por cada um. (PLATÃO, Protágoras, 320.)

Em Hesíodo, é Hefaístos que, para vingar Zeus da hybris e dos ardis prometeicos (o roubo do fogo e o banquete de tolos), modela a terra encharcada de água à imagem de

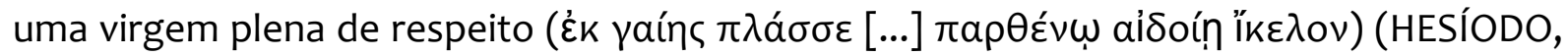
O trabalho e os dias, 70s), enquanto no belo seio de Pandora, Hermes "prepara palavras

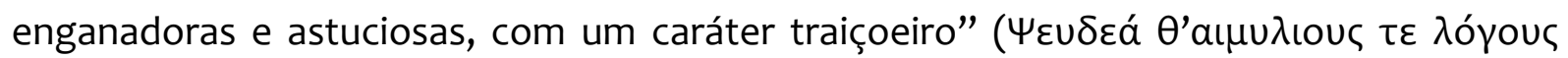

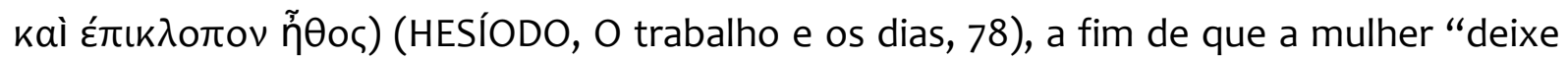
nos homens as preocupações funestas e que assim a modelagem encontre, de uma vez por todas, o paradigma de sua duplicidade". (CASSIN, 2005, p. 218)

Cassin, em seguida, recorre a um fragmento de Górgias para compreendermos melhor a distância que separa esse $\psi \varepsilon \tilde{\delta} \delta$ oc inteiramente negativo imputado à sofística pela filosofia de um $\psi \varepsilon \tilde{\delta} \delta o \varsigma$ produto da atividade plástica: a ficção. Em história, o historiador desempenha essa atividade demiúrgica, na medida em que molda a história em um tipo ou outro de narrativa, ao mesmo tempo em que a narração histórica "performa os acontecimentos tanto quanto ela os constata". ${ }^{10} \mathrm{Em}$ todo caso, jogar "esse jogo tão demiúrgico quanto o da criança heraclitiana”, nas palavras de Cassin, não é “nem

\footnotetext{
${ }^{10}$ Ver: WHITE, Hayden. Metaphysics of narrativity. Artigo dedicado a Temps et Récits I e II. In: The Content of the Form: Narrative Discourse and Historical Representation. Baltimore/London: The Johns Hopkins University Press, 1990. p. 169-184.
} 
insolência, nem ingenuidade, tagarelice ou imaturidade, mas sabedoria e justiça", justamente porque:

Aquele que ilude é mais justo do que aquele que não ilude, e aquele que é iludido, mais sábio que aquele que não é iludido. Aquele que ilude é mais justo porque realiza o que prometeu, e o que é iludido, mais sábio, pois ser facilmente arrebatado pelo prazer dos discursos é não ser privado de sensibilidade (anaistheton). (PLUTARCO, Da Glória dos Atenienses, 5, p. 348c)

Segundo Cassin, este fragmento de Plutarco nos é transmitido como relativo à tragédia: Justiça - fundamento da cidade; Sabedoria - fundamento da paideia, na relação de ambas com a tragédia. Essa imbricação entre literatura, pedagogia e política é o caminho a que o plasma conduz. Nessa linha de raciocínio, ela retoma seu conceito de efeito-mundo, ao qual já fizemos referencia: por um lado, o efeito-mundo produzido então no mundo humano, através do consenso que constitui a cidade; por outro, o produzido no âmbito da ficção literária - cultura em oposição à incultura, do patrimônio que constitui a identidade de um povo (não esqueçamos: White analisa a historiografia do século XIX, que foi também, como sabemos, marcadamente nacionalista). A ponte entre ambos os espaços de produção do efeito-mundo: a paideia. (CASSIN, 2005, p. 219)

Sofística e ficção. A sofística apresenta então sua crítica à ontologia. O fragmento de Górgias é entendido, dessa forma, como um indicador da "função social da literatura", assinalando que a questão da persuasão - "persuadir um auditório de que o que não é verdadeiro é verdadeiro" - conduz claramente à ficção (ao que não é verdadeiro). Mas a ideia de ficção é "uma ideia sofisticada", acrescenta, pois: "a ficção se situa em algum lugar entre as ideias de verdadeiro e de falso, entre fato e não-fato". A ficção, desse modo, guarda alguma relação com a falsidade, mas também com o verdadeiro. Em seguida, citando Reardon (1991), finalmente vem o exemplo que mais nos interessa:

Uma criança fabrica histórias. Elas não são nem verdadeiras nem, salvo em um sentido superficial, falsas [...]. No início, "verdadeiro" e "nãoverdadeiro" não são de modo algum categorias em seu espírito. Em um dado momento, entretanto, ela tomará consciência de que a ficção, mesmo se ela puder não ser repreensível, não é fato. (REARDON, 1991, p. 57) 
Este "é o momento em que sobrevém a sofisticação" (CASSIN, 2005, p. 57). Ficção, mesmo que não repreensível, não fato; ou ficção, mesmo não fato, não repreensível. 0 mesmo raciocínio encontraremos na argumentação de Reinhart Koselleck (2006), na terceira parte de sua obra Futuro Passado. O capítulo 12, intitulado Terror e sonho: anotações metodológicas para as experiências do tempo no Terceiro Reich, inicia com a sugestiva frase de Alsted: “Aquele que inventa peca contra a história; aquele que não inventa peca contra a poesia" (Si fingat, peccat in historiam; si non fingat, peccat in poesiam). (KOSELLECK, 2006, p. 247) Koselleck, fazendo referência a dois sonhos da época do Terceiro Reich, procura evidenciar o que ele chama de "inevitável facticidade do fictício", da qual os sonhos, obviamente ficcionais, são representantes. São breves, passemos a eles:

A primeira história provém de um médico, do ano de 1934. "Depois da consulta, pelas nove da noite, quando quero estender-me tranquilamente no sofá folheando um livro sobre Matthias Grünewald, minha sala e minha casa de repente ficam sem paredes. Olho espantado ao redor e todas as casas, a perder de vista, não tem mais paredes. Ouço um alto-falante berrar: 'Conforme o decreto sobre abolição das paredes do dia 17 do corrente mês....'”

A outra história é também da década de 1930 e provém de um advogado judeu: "Dois bancos existem no Tiergarten, um verde, como de costume, e o outro amarelo (os judeus, então, só podiam sentar-se em bancos pintados de amarelo), e entre os dois há um cesto para papel. Sento-me no cesto e eu mesmo penduro um letreiro, como fazem por vezes os mendigos cegos e como também as autoridades obrigam os 'violadores da raça' a fazer: "Se for necessário, deixarei lugar para o papel'. (KOSELLECK, 2006, p. 252)

Como o próprio Koselleck conclui, as duas historinhas sonhadas pertencem manifestamente ao gênero dos textos de ficção, mas, "precisamente como ficção, elas formam um elemento da realidade histórica" (KOSELLECK, 2006, p. 254) para quem conheceu o que se realizou no Terceiro Reich. De qualquer forma, seja no exemplo evocado por Cassin sobre as histórias das crianças, seja nos sonhos mencionados por Koselleck - os sonhos de terror -, o que está em evidência é uma ideia sofisticada que busca descompartimentar os gêneros entre história e ficção, separados desde Aristóteles. Como expressa Cassin, uma vez que se aceite esse ponto de vista da sofística, a áđá́tᄁ, a ilusão que se encontra relacionada não somente à justiça e à sabedoria, mas, 


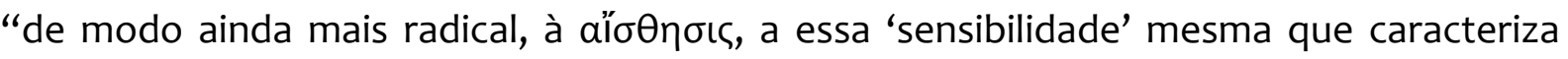
nossa relação com o mundo", o campo de trabalho filosófico - e aqui propriamente histórico -, passa a ser de algum modo complementar em relação ao sentido.

Não se trata mais de coagir a certa auto-regulamentação da linguagem, ainda que persista a questão: "como garantir que são o mundo, o real, os fenômenos, eles e nada além deles - qualquer que seja sua complexidade ou a complexidade de sua simplicidade - que passam nas palavras?" (CASSIN, 2005, p. 220) Quem responde a isso? White responde: “Não há apodicticamente premissas teóricas [...] em que se possa de forma legítima assentar [...] que um dos modos [de narrativa] é superior aos outros por ser mais 'realista”' (WHITE, 1995, p. 14) A escolha é estética, não epistemológica, ele conclui." White e a sofística contra a ontologia.

Diante dessa estetização, é preciso retomar a noção de plasma que vínhamos seguindo no rastro de Cassin. Fazendo referência a um texto de Luciano, intitulado Para

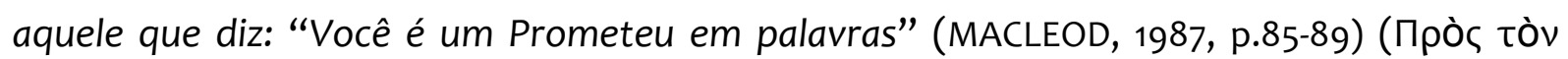

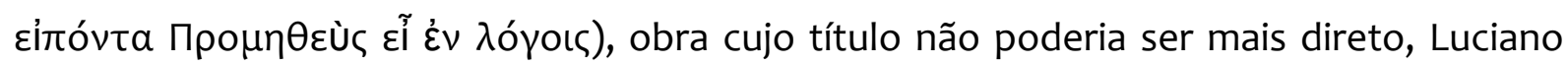
faria eco ao $\pi \lambda a ́ \sigma \sigma \varepsilon \iota \nu$, comenta ela. Não nos cabe analisar a obra de Luciano aqui, mas apontar seu principal argumento: “O homem não é, portanto, apenas moldado ou dotado por Prometeu, ele mesmo é prometeico na medida em que modela seus discursos e 'ficcionaliza"”. (CASSIN, 2005, p. 221)

É em Sexto Empírico (Adversus Mathematicos, I, 248-269), porém, que Cassin encontra a melhor conceituação para a relação entre história e plasma, e como o plasma

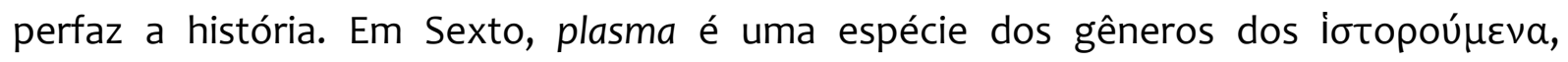

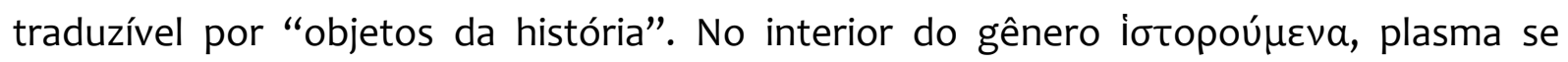
encontra ao lado de outras duas espécies: o $\mu$ ŨӨos e a própria história. A diferença entre as três espécies se exprime, como veremos, na relação delas com o verdadeiro, o falso e

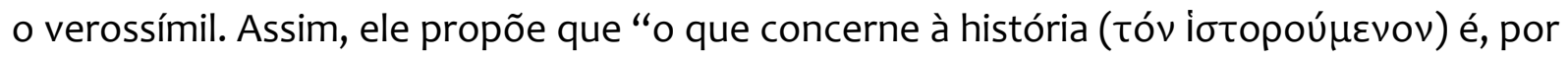
uma parte, história (história); por outra, mito ( $\mu$ ŨӨoৎ) e, por uma terceira, ficção (plasma)". A história, no sentido amplo, no sentido do que se tornou nossa disciplina,

\footnotetext{
11 "Como corolário disso, os melhores fundamentos para escolher uma perspectiva da história em lugar de outra são, em última análise, antes estéticos ou morais que epistemológicos". WHITE, Hayden. op. cit., 1995. p. 14.
} 
kaí $\psi \varepsilon \cup \delta \tilde{\omega} v)$ - "aranhas e serpentes saindo vivas do sangue dos Titãs, Pégaso saltando da Górgona degolada e outras metamorfoses"; como os companheiros de Diomedes tornando-se gaivotas; Ulisses, em cavalo e Hécuba, em cão. Por fim, a ficção narra "coisas que não aconteceram, mas que são narradas como as que aconteceram" ( $\pi \rho a \gamma \mu a ́ \tau \omega \nu \mu \varepsilon$

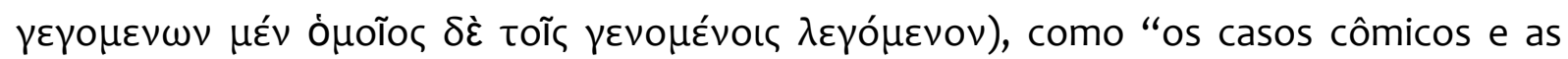
pantonímias". (CASSIN, 2005, p. 226)

Sexto estabelece assim o plasma - e a ficção - não mais ao lado do falso (do pseudos), mas do verossímil, do “como verdadeiro”. Esse movimento, observa Cassin, faz a poesia desdobrar-se para além dos limites impostos pela "oposição maciça e maciçamente aristotélica entre a história e a literatura":

A diferença entre o historiador e o poeta não está no fato de um se exprimir em verso e o outro em prosa (poder-se-ia colocar em verso a obra de Heródoto, não seria menos história em verso do que em prosa); mas a diferença é que um diz o que acorreu, o outro o que poderia

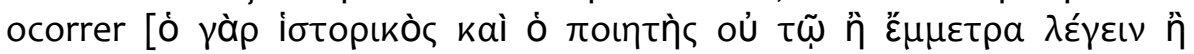

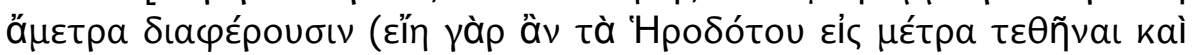

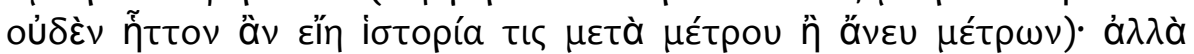

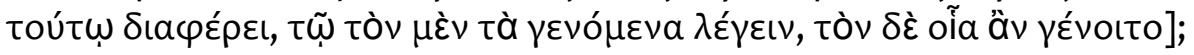
é por essa razão que a poesia é mais filosófica e mais nobre do que a

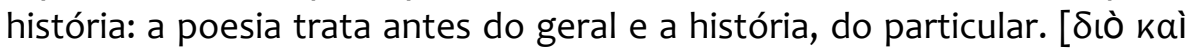

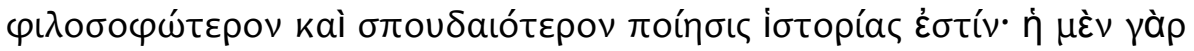

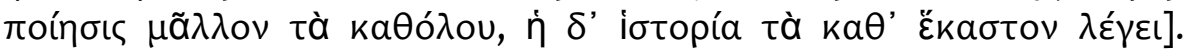
(ARISTÓTELES. Poética, 1451 a39-b7)

Esta é a passagem de Aristóteles que compartimentou em gêneros separados poesia e história. Mas na perspectiva de Sexto, onde há descompartimentação, o plasma perfaz a história, fazendo efetivamente passar ao geral, elevando-a, através do seu “como se", ao plano da atividade prometeica. Nas palavras de Cassin, "o verossímil é

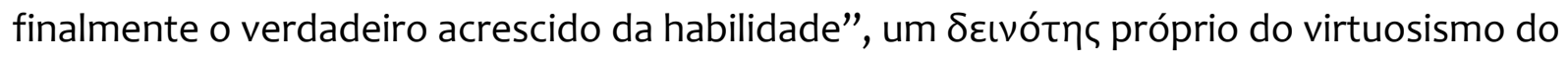
orador. Nesse sentido, o plasma (ficção) na história é superior, do mesmo modo como era a poesia em Aristóteles, e pela mesma razão! (CASSIN, 2005, p. 231-232) 
Esta interpretação ecoará também na análise que François Hartog (2011) faz a respeito de Tucídides, em seu Evidência da história: o que os historiadores veem. No capítulo intitulado O Olhar de Tucídides e a história "verdadeira", ele retoma a questão dos discursos em Tucídides (com efeito, Tucídides inventa, ou, na melhor das hipóteses, “ficcionaliza" os discursos de sua História da Guerra do Peloponeso, na medida em que não poderia tê-los testemunhado). O discurso, inegavelmente, será tratado então como uma "mentira da forma", pois é inventado. Mas o importante aqui para nós é a observação de Hartog: "No fundo, o historiador moderno faz algo semelhante a Tucídides: a seu exemplo, ele 'interpreta', mostra a 'lógica interna' de uma série de atos”. Em consequência, a "verdade do fundo" (a moral da história) permanece incólume diante da "mentira da forma" (os discursos). Em Tucídides, a narrativa é pura sucessão factual, enquanto o discurso exprime o geral, a lei, o universal, o filosófico, a causa, a permanência da natureza humana. Por isso Hartog afirma: “Mesmo que haja mentira, não há, portanto, mentiroso". Eis, de qualquer forma, um Tucídides desculpado e absolvido. (HARTOG, 2011, p. 86-88) No fim, o argumento é o mesmo evocado por Koselleck sobre os sonhos de terror no Terceiro Reich e, alguns séculos antes, a defesa que a sofística e o ceticismo fizeram do plasma. De Tucídides aos historiadores modernos: todos prometeus e sofistas. E a história, um plasma.

\section{Referências}

ANKERSMIT, Frank. Truth in literature and history. In: Geschichstdiskurs. Band5: Globale Konflikte, Erinnerungsarbeit und Neuorientierungen seit 1945, Wolfgang Küttler, Jörn Rüsen, Ernst Schulin Hrsgb. Frankfurt am Main: Fischer Taschenbuch Verlag, 1999.

ANKERSMIT, Frank. Historicismo, pós-modernismo e historiografia. In: MALERBA, Jurandir (Org.). A história escrita. São Paulo: Contexto, 2006.

ARENDT. Hannah. A vida do espírito: o pensar, o querer, o julgar. Rio de Janeiro: Civilização Brasileira, 2010.

ARISTÓTELES. Metafísica. Tradução de Leonel Vallandro. Porto Alegre: Editora Globo, 1969. 
ARISTÓTELES. Retórica. Introdução de Manuel Alexandre JÚNIOR. Tradução do grego e notas de Manuel Alexandre Júnior, Paulo Farmhouse Alberto e Abel do Nascimento Pena. Lisboa: INCM, 1998.

CASSIN, Barbara. O efeito sofístico: sofística, filosofia, retórica, literatura. São Paulo: Ed. 34, 2005.

DETIENNE, Marcel. Les Maîtres de Verité dans la Grèce archaïque. Paris: Maspéro, 1981.

GADAMER, Hans-Georg. Verdade e método: traços fundamentais de uma hermenêutica filosófica. Tradução de Flávio Paulo Meurer. Petrópolis: Editora Vozes, 1997.

HARTOG, François. Evidência da história: o que os historiadores veem. Belo Horizonte: Autêntica Editora, 2011.

HESíODO. Teogonia. Tradução de José Antônio Alves Torrano. São Paulo: Massao Ohno e Roswitha Kempf Editores, 1981.

KOSELLECK, Reinhart. Futuro passado: contribuição à semântica dos tempos históricos. Rio de Janeiro: Contraponto Ed. PUC-Rio, 2006.

LA CAPRA, Dominik. Representing the holocaust: reflections on the historians' debate. In: FRIEDLAND, Saul (Org.). Probing the limits of representation. Cambridge, London: Harvard University, 1992.

MACLEOD, Matthew Donald. Luciani Opera. Oxford: Clarendon Press, 1987, t. IV (livro 71), p. 85-89, com tradução para o inglês de K. Kilburn, Lucian, Londres/Cambridge, loeb, 1968.

PINTO, Maria José Vaz. A doutrina do logos na sofística. Lisboa: Ed. Colibri, 2000.

PLATÃO. Teeteto e Crátilo. Tradução de Carlos Alberto Nunes. Belém: EditoraUniversitária UFPA, 2001.

REARDON, Bryan P. The Form of Greek Romance. Princeton: Princeton University Press, 1991.

SMITH, Bárbara Herrnstein. Crença e resistência: a dinâmica da controvérsia intelectual contemporânea. São Paulo: Editora UNESP, 2002.

SOUTHGATE, Beverly. History: what and why? ancient, modern ans postmodern perspectives. London/New York: Routledge, 1996.

VEYNE, Paul. Como se escreve a história. Lisboa: Edições 70, 1987. 
WHITE, Hayden. Meta-história: a imaginação histórica do século XIX. São Paulo: Editora da Universidade de São Paulo, 1995.

WHITE, Hayden. Metaphysics of narrativity. Artigo dedicado a Temps et Récits I e II. In: The Content of the Form: Narrative Discourse and Historical Representation. Baltimore/London: The Johns Hopkins University Press, 1990. 